\title{
A PSYCHOLOGICAL PERSPECTIVE ON GOD-BELIEF AS A SOURCE OF WELL-BEING AND MEANING
}

\begin{abstract}
Authors:
E. Karen van der Merwe ${ }^{1}$ Chrizanne van Eeden ${ }^{2}$ Hans J.M. van Deventer ${ }^{3}$
\end{abstract}

\begin{abstract}
Affiliations:
${ }^{1}$ Department Psychology, North-West University, Vaal Triangle campus, South Africa

${ }^{2}$ School of Behavioural Sciences, North-West University, Vaal Triangle campus, South Africa
\end{abstract}

${ }^{3}$ School of Basic Sciences, North-West University, Vaal Triangle campus, South Africa

\section{Correspondence to:}

Hans van Deventer

email:

hans.vandeventer@nwu. ac.za

\section{Postal address:}

PO Box 1174

Vanderbijlpark 1900,

South Africa

\section{Keywords:}

God-image; God-concept;

African religion; Christian religion; meaning;

psychological well-being

\section{Dates:}

Received: 12 Aug. 2009

Accepted: 29 Dec. 2009

Published: 18 June 2010

How to cite this article:

Van der Merwe, E.K.,

Van Eeden, C. \& Van

Deventer, H.J.M., 2010, 'A

psychological perspective on god-belief as a source of well-being and meaning', HTS Teologiese Studies/ Theological Studies 66(1), Art. \#332, 10 pages. DOI: 10.4102/hts.v66i1.332

\section{This article is available} at:

http:/ / www.hts.org.za

(C) 2010. The Authors. Licensee: OpenJournals Publishing. This work is licensed under the Creative Commons Attribution License.

\section{ABSTRACT}

This article reports on a qualitative exploration of the well-being and meaning that second- and third-generation Christians from an African context experience because of their integration of religion in their life and being. A textured, integrated tapestry is created of the participants' understanding of God (God-concept), experience of their relationship with God (God-image) and understanding of life as coloured by their belief systems. The contribution of their God-belief to their sense of meaning and psychological well-being frames the tapestry of this article.

Religion is not primarily a set of beliefs, a collection of prayers, or a series of rituals. Religion is first and foremost a way of seeing. It can't change the facts about the world we live in, but it can change the way we see those facts, and that in itself can often make a difference.

(Kushner, cited in Pargament 1997:193)

\section{INTRODUCTION}

There was a time when religion was the absolute source of all knowledge and meaning (Pargament 1997). The unquestioning acceptance of views of the universe proclaimed by religions was the cast for peoples' worldviews; it provided a frame for understanding reality, creating meaning and directing behaviour.

The penchant to create higher-order meaning and the need for religion seems to be hardwired into humans as a by-product of evolutionary adaptations (Baumeister \& Vohs 2002). Psychoanalysts explain the belief in God in terms of the projection of unmet needs on an idealised parental figure. According to Freud and Rizzuto (Rizzuto 1979; Wulff 1997), believers shape their personal image of God through a process of identification with both parents (objects) during infancy, from which parental imagos are formed. These imagos are the ground of God representations (Goodwin 1998; Wulff 1997; Rizzuto 1979). Religion is seen as wish-fulfilment. Religions provide comfort to believers; fear and anxiety are alleviated by the belief in a powerful being (Goodwin 1998; Guthrie 1993; Rizutto 1979), frequently metaphorically referred to as a Father, who is lovingly involved in the personal details of everyday life. God cannot be seen or experienced directly, therefore believers acquire a concept of God according to the understandings of their religion and culture (the dominant social construction of God).

Evolutionary and psychoanalytic theories provide possible answers concerning the reason why, universally, humans are religious. The question then arises: how does a belief in God contribute to an individual's well-being? Do the expectations, linked to the acknowledgement of a higher Presence and the consequent correctives on behaviour, add or detract from people's well-being?

\section{RELIGION AND WELL-BEING}

Research in psychological well-being is ongoing - the focus is on the identification, clarification, description of character strengths and constructs essential to psychological well-being, and synthesising the constructs into coherent theories of psychological well-being (Wissing \& Temane 2008). The understanding of virtue and character strengths flowing from virtuous choices and behaviour is a core component of positive psychology and has led to the values in action classification system of human strengths. The identification of a common set of human qualities universally regarded as virtues was achieved by examining virtues and values honoured by most philosophical, religious and cultural traditions in the world (Van Eeden et al. 2008). Eventually, six virtue clusters - wisdom, courage, humanity, justice, temperance and transcendence - were selected and these virtues are proposed to be manifested by twenty-four character strengths. Peterson and Seligman (2004) see these virtues and strengths as building blocks of psychological health and well-being - a life well lived. Virtue clusters and their defining character strengths are:

- Wisdom and knowledge - cognitive strengths that entail the acquisition and use of knowledge: curiosity, love of learning, open-mindedness, creativity, perspective.

- Courage - emotional strengths that involve the exercise of will to accomplish goals in the face of opposition, external or internal: valour or bravery, persistence, integrity or authenticity, zest or vitality.

- Humanity - interpersonal strengths that involve tending and befriending others: love, kindness, social intelligence.

- Justice - civic strengths that underlie healthy community life: citizenship, fairness, leadership.

- Temperance - strengths that protect against excess: self-regulation, prudence, forgiveness and mercy, modesty and humility.

- Transcendence - strengths that forge connections to the larger universe and provide meaning: appreciation of beauty and excellence, gratitude, hope, humour and playfulness, spirituality or religiousness.

(Van Eeden et al. 2008:143) 
Ryan and Deci (Compton 2005; Wissing \& Temane 2008) suggest the division of the numerous conceptualisations of well-being into two categories, namely hedonic and eudaimonic well-being. The hedonic approach describes the pleasant life and the good life in terms of pleasure, happiness and life satisfaction. The subjective well-being model (Diener et al. 1999) represents the hedonic perspective on well-being. The eudaimonic perspective focuses on the good life and the meaningful life, in which fulfilling one's own potential and living according to one's own values and virtues are the motivating drives (Compton 2005; Seligman 2002; Wissing \& Themane 2008). Ryff's sixdimensional model of psychological well-being (Ryff \& Singer 1996) expresses the eudaimonic view of well-being. Seligman (2002) indicates that the good life is more than the pleasant life and that the meaningful life is more than the good life. He is of the opinion that the meaningful life is characterised by finding meaning in life's issues and challenges and in attachment to some entity larger and beyond oneself, such as committing to a good cause and/or to religion.

\section{MEANING AND WELL-BEING}

The fact that defining the term 'meaning' is difficult (Park 2005) does not detract from the reality that all humans search for meaning (Frankl 1978; Pargament \& Hahn 1986). 'Meaning is a tool for adaptation, for controlling the world, self-regulation, and belongingness. Indeed it is the best all purpose tool on the planet' (Baumeister 1991:357-358). Baumeister \& Vohs (2002:610, 611) name four needs that underlie our need for meaning:

- The need for purpose lies in setting and striving towards both objectively attainable goals (promotion) and subjective goals in the form of fulfilment (happiness). Religion provides all-encompassing goals regarding good, righteous living (Park 2005).

- The need for value is the foundation for a sense of goodness. Values are needed as they provide security that behaviour is acceptable, thus buffering the self against feelings of guilt and anxiety. Religions are exceptionally powerful sources of values. Clear criteria for what is deemed acceptable and unacceptable are provided (Park 2005).

- The need for a sense of self-efficacy, which is linked to a belief that one has some control over life and can make a difference in life.

- The need for basic self-worth is pursued by every individual. Some individuals accentuate a sense of individual self-worth, while others follow the path of collectivism, achieving selfworth through belonging to a specific group.

Although these needs are fulfilled by multiple sources, such as love, work and family, religion provides the framework for meaning, as the quintessence of meaningfulness is connectedness (Baumeister \& Vohs 2002; Leontiev 2006; Post 1996) - that is, connectedness with God, self and others. People who live in a relationship with a responsive God report higher levels of personal well-being, as opposed to those who experience God as distant and punitive (Pargament \& Mahoney 2002).

\section{MEANING AND RELIGION}

Religious traditions provide a body of shared assumptions of an intelligible and orderly world (Montell 2001; Pargament 1997). In this article, Baumeister's (1991) definition of religion is used, namely that religion provides

.. a set of doctrines about natural and supernatural reality that enable people to understand their broader, ultimate context. Religion guarantees that whatever happens to the individual, no matter how good or bad makes sense. Thus, religious beliefs provide a framework for perceiving, understanding and evaluating daily events, experiencing them as part of a broader pattern.

(Baumeister 1991:184)

Religion causes as much cognitive dissonance as it resolves uncertainty (Ozorak 2005), which leads Montell (2001:122) to argue that most people live comfortably with this dissonance because humans compartmentalise - belief in natural causality is preserved primarily for 'physical warfare' and belief in supernatural forces are activated primarily for 'spiritual warfare'.

Many, if not most, religions and biblical ideas regarding the natural and supernatural world date from a pre-modern world and do not necessarily coexist in harmony with modern or postmodern notions (Wilber 2007). Scientific advances have explained many phenomena, for example disease and weather patterns, which were previously thought to have had a supernatural cause. All humans (to a degree) intuitively understand natural laws of causality, but many religious people also believe in the counterintuitive notion that God can, and does, suspend natural laws (Dennet 2006; Montell 2001). The simultaneous holding of opposing, logically inconsistent notions causes cognitive dissonance (Festinger 1957), resulting in psychic tension and anxiety which motivate strategies to reduce dissonance and therefore also anxiety (Burris, Harmon-Jones \& Trapley 1997; Western 1999). Such strategies include a change of belief (Western 1999), belief intensification by inter alia religious attributions (Ozorak 2005) and transcendence where conflicting notions are reconciled under a superordinate concept (Burris et al. 1997). Believers who are willing to intellectually confront the discrepancies are motivated to change beliefs. Spong (2001) suggests that the discrepancy between scientific data and biblical cosmology (the understanding of the universe and humans place in it) has become untenable and that Christianity should fundamentally change in order to bring religious notions in line with modern scientific understanding. Few people intellectually confront the discrepancies, but rather use religious attributions to bolster their belief. In an effort to reconcile, for example, financial misfortune with a loving, providing God, these people make naturalistic attributions (the general economic situation) and religious attributions (God wants to teach me prudence).

The salience of beliefs (naturalistic or religious) largely determines which attribution will be made; in situations of high uncertainty or imminent danger, religious attributions are more likely to be made (Gorsuch \& Smith 1983; Hertog \& Gow 2005; Park 2005). Attributions are made to help people maintain their sense of control and meaning (Pargament \& Hahn 1986). In the previous example of financial misfortune, transcendence would be achieved by a belief such as 'God is in absolute control and $\mathrm{He}$ has a bigger plan with my life'. The beliefs and attributions help people to cope with anxiety and create meaning. All religious coping mechanisms have the same purpose: the enhancement of significance (meaning) (Pargament 1997). Religious coping is more likely to be found in individuals who are more religiously committed and involved and have fewer other non-religious alternatives and resources available.

Religious pathways vary in their importance and embeddedness in peoples' lives (Pargament 1997). The relationship between religiousness and a sense of meaning is apparent, but the strength of the relation is modest and linked to different ways of being religious:

- Extrinsic religiousness is utilitarian and self-serving as the focus is on what it offers, namely support for one's preferred life style. This type of religiousness is inversely related to sense of meaning in life and mental health (Park 2005; Argyle 2000; Pargament 1997).

- Intrinsic religiousness centres on God as the source of meaning and purpose. The motive to live, according to God's will, permeates the believer's whole life, provides a framework for meaning and is associated with high selfesteem and a positive image of God (Park 2005; Argyle 2000).

- Religion as quest is largely a cognitive path within which there is a persistent search for truth, coupled with an acceptance that absolute truth may never be found. People with a quest orientation sincerely confront the difficulties 
of existential problems, while simultaneously refusing to accept pat answers. There are mixed findings regarding the effects of a quest orientation (Pargament 1997). Uncertainty may lead to depression and anxiety, but may also be rewarding, as it provides an impetus for progression on a spiritual journey that may lead to the development of personal beliefs in response to the challenges of life (Miller \& Kelley 2006).

Religion sets a more or less clear path for spiritual growth. According to Emmons (2006:65), '[p]eople are spiritual to the degree to which they are trying to know, find, experience, or relate to what they perceive as sacred'. Thus, spirituality is the essence of all religions (Dreyer 2003; Rassool 2000). Irrespective of the dogmatic differences between religions, religious belief systems provide their adherents with integrated global meaning systems which are incorporated in their worldviews (Ozorak 2005; Park 2005; Koltko-Rivera 2004; Pyysiäinen 2003).

\section{AFRICAN WORLDVIEW}

In African cosmology, God created and sustains two interrelating spheres of reality: the visible and the invisible (Kalilombe 1999, 1994). God is distant and not involved in humans' everyday life. In this cosmology, a view of mystical causality prevails; it is believed that powerful natural and supernatural forces govern everyday events, and that spiritual beings guide, protect and chastise the living (Kasambala 2005; Zahan 2000; Mbiti 1991). According to this magical worldview (Wilber 2007), the dominant emotion is fear, as people feel they have no control over, nor understanding of, these forces and therefore resort to the use of elaborate rituals to protect themselves and benefit others (Kasambala 2005). Traditional African religion posits that God departed from earth and humans; thus, a need for intermediaries developed. This role is fulfilled by the ancestors who are the superhuman spirits of those who have passed on (Kasambala 2005). A defining feature of African culture is the emphasis on relationships. This is the central value that gives meaning to life within an African community (Kasambala 2005). At the centre of African spirituality lies the core issue of relationship. Spirituality is communal and corporate and relies on cooperation, the sharing and redistribution of resources amongst kin (Kalilombe 1999).

\section{CHRISTIAN WORLDVIEW}

The Christian worldview is framed by the belief that God is the creator who is intimately involved in humans' lives. All humans are fallen sinners in need of redemption through Christ in order to enjoy a restored relationship with God (Nürnberger 2007). A worldview that is dominated by such concepts, rules and roles could be described as mythic (Wilber 2007). Fear is also an underlying emotion, as disobedience is punished, ultimately, by everlasting condemnation. It would be a gross generalisation to assume that all Christians subscribe to this mythic worldview. Scientific developments in exegesis, hermeneutics and historic analyses have filtered down to many Christians - changing their worldview from mythic to modern, or even post-modern (Craffert 2008; Spong 2001). At the risk of over-generalising, one could classify both African and traditional Christian worldviews as pre-modern: the African worldview, magical and Christian worldview, mythical (Wilber 2007). Unquestioning acceptance of age-old teachings, principles and rituals is the common denominator. Through participation in religious rituals, beliefs are enhanced and group association established (Sossis 2006).

The Christianity that was brought to Africa during colonisation had been influenced by rationalism, which became the dominant force since the era of enlightenment. The African and western Christian worldviews thus differ in that the western Christian worldview supports the notion of an open universe whereas the traditional (intuitive) African worldview supports one of a bounded universe. Fundamental differences between the worldviews are evident: the western Christian worldview is characterised by an extended concept of time, including a vast history and open future; alternative knowledge systems are acknowledged and the social world is extended to include increasingly wider spheres (Hammond-Tooke 1998). The western worldview can be described as rational. It is associated with an epistemology of reason, which has been shaped by a broad spectrum of philosophies, both Christian and non-Christian. In the African worldview, time is conceived as two-dimensional: it has a long history, a present and virtually no future, the tempo of living is slow and the here-and-now is important (Viljoen 2003). Furthermore, social horizons are limited and all a person's physical and social needs are met from within the intimate circle of kin (Hammond-Tooke 1998). Although care and being responsible for the collective well-being of society are primary values in both worldviews, the African worldview is associated with collectivism, while the western Christian worldview is linked to individualism. These worldviews provide different sets of boundaries for understanding who humans are, how they could and should live and what forces impact their lives.

At the core of religion is the belief regarding ultimate reality God. All religions teach notions of God and people form their own internal representation of God. Thus, a distinction is made between a God-concept and God-image (Meier \& Meier 2004; Lawrence 1997; Rizzuto 1979). A God-concept is one's cognitive knowledge of God, while a God-image is the experiential, emotional knowledge of God (Rizzuto 1979). The theologically taught God-concept is intimately linked, but not identical, to someone's God-image, which is dominant in the believer-God relationship.

African religions hold what, from a Western perspective, can be described as a deistic concept of God; a God who created everything, but who is distant and uninvolved in human life (Kalilombe 1999). Humans cannot directly communicate with God and are therefore dependent on special, or chosen human and spirit intermediaries. The Christian understanding of God is that of the Creator Father, Son as Redeemer and Mediator, and Holy Spirit who dwells in the redeemed sinner (Holy Trinity), thus a theistic concept of a personal God who is intensely involved in the life of the individual. African Christians make a conceptual shift regarding their understanding of God from what could be described as a deistic to a theistic view. The empirical data discussed below shows that the participants make the shift apparently seamlessly and that it results in personal empowerment and changed self-perception.

\section{AIM AND METHODOLOGY}

The aim of the study, which was planned by the three authors but executed by the first author, was a quest for in-depth understanding ('verstehen') of the meanings and interpretations (Burrell \& Morgan 1979) that Christians coming from a traditional African context attach to, and derive from, their belief in God. To achieve this aim, we decided to explore the experiences of the participants by asking the following questions during the interviews:

- Where did you learn about God? (religious background)

- How would you describe God? (God-concept)

- How do you experience God? (God-image)

- Tell me about your prayer life (God-image, expectations and needs, creation of meaning)

- According to traditional African beliefs, bad things can be caused by malicious people and other forces. What is your belief in this regard? (Integration of African and Christian beliefs)

- How do you make sense of our Apartheid past where discrimination was legitimised by a specific reading of the Bible? (Creation of meaning in the face of suffering).

The aim could be achieved within a qualitative, interpretive (hermeneutic) methodological paradigm (Nieuwenhuis 2007a; 
Guba \& Lincoln 1994). The understanding (constructions of meaning) of who God is and the meaning of religious experiences are understood as being influenced by the African and Christian culture, religion, historic-political time frame and day-to-day social existence. The interplay between the individual's creation of meaning and the context was therefore of vital importance during data analysis and interpretation. Following the relativist epistemological assumption that knowledge is context-bound the analysis of data and outcome of the process (findings) are partial and subjective and only one possible interpretation of reality (Taylor \& Bogdan 1998).

\section{Research instrument}

Given that the task was to enter the context and discern the emic views, the only possible research instrument was the person of the researcher (Guba \& Lincoln 1994) - namely, the first author, who was a devout Christian, but because of various influences and experiences, now describes herself as a 'believer in exile' (Spong 1999:22). Her position as researcher was one of learner, but her worldview (determined by her nationality, culture, religion, knowledge and values) could not, by definition, be divorced from the research process, which is subjective and, as such, value laden and biased (Creswell 1994). Therefore, her humanness and intuition were fundamental elements used in the research process to inform and guide the inquiry (Nieuwenhuis 2007a).

\section{Design type}

The focal point of the study was a group of Christians from a traditional African context, individuals who shared the same cultural and religious context. A case-study design was used, which is ideally suited to an in-depth study, wherein the answers to 'how'- and 'why'-questions are sought (Babbie 2007; Nieuwenhuis 2007b)

\section{Sampling}

The aim of the research provided the main criteria for sampling: African people who were Christians needed to be interviewed in English, as the interviewer was not conversant in the native language of the interviewees. Furthermore, during the planning process, the author was sensitive to the power imbalance inherent in the research situation and did not want to interview individuals who might have felt intimidated by the process. It was thus decided to focus on more educated individuals and purposive sampling was used (Maree \& Pietersen 2007). Participation was voluntary and all participants were fully informed of the aim, process and outcome of the investigation before obtaining their written consent. Confidentiality was respected by using pseudonyms in the discussion of data.

\section{Data collection}

Over a period of five months, individual interviews were conducted, digitally captured, transcribed and reflected upon in the light of the research questions. The number of interviews was determined by data saturation (Grbich 2007). Twelve participants, eight male and four female, in the age group 25-65 years were interviewed in sessions of between 1 hour and 1.5 hours. In total, 14 hours of audio material was transcribed for detailed analysis.

\section{Data analysis and interpretation}

The principle of the hermeneutic circle - the part-whole relationship was always considered during the interpretation of data (Gadamer 1982; Burrell \& Morgan 1979). The individual constructions (the parts) were seen as expressions of a particular socio-religious environment (the whole). We chose well-being and meaning, within the framework of the positive psychology, as the scope for the interpretation of participants' religious experiences (Gadamer 1982).

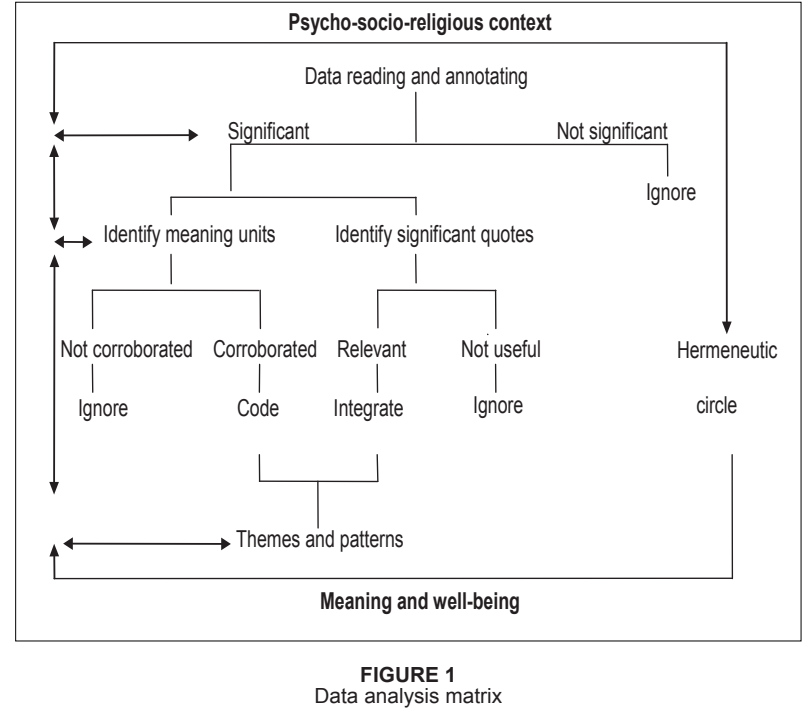

The process of analysis started with a rigorous effort of immersion in the data (Terre Blanche, Durrheim \& Kelly 2007), noting impressions, intuitions and ideas. The texts were then analysed by identifying units of meaning and significant quotes which captured the essence of these meanings. The next step included coding, searching for, and identifying themes (categories) and patterns that synthesised meaning units that were corroborated in all, or most, of the interview protocols (Babbie 2007; Alvesson 2002) (Figure 1). A reflective team (Jones 2004), including a specialist in positive psychology, a theologian and an African priest (who is a registered psychological counsellor) were involved in the data analysis.

\section{Quality}

In order to make a defensible claim regarding the truth of the co-created interpretation (knowledge), meticulous care was taken to keep close to the data at all times, to look for alternative explanations, while considering the impact of the researcher's own experiences, thoughts and being in every aspect of the study. The participation of a reflective team ensured investigator triangulation (Kelly 2007c). By being as thorough as possible, credibility and trustworthiness were enhanced (Schwandt 1994). Babbie and Mouton (2001) argue that a demonstration of credibility is sufficient to establish dependability. Coherence between all aspects of research was maintained in order to create useful interpretations worthy of adoption (transferability) (Kelly 2007a; Schwandt 1994).

\section{SETTING}

\section{Socio-political and religious complexities}

Presently, South Africa is 14 years into a democratic dispensation. Religious injustices of the past, notably the arrogance with which Western missionaries came to Africa to 'civilise' Africans, while disrespecting the latter's religion, have left a mark on the African psyche as the data will show. Though social integration is slow, clear progress has been made in terms of understanding and acceptance between different race groups. The role of religion in this regard will become clear in the discussion of the empirical data.

Participants were urban 2nd- and 3rd-generation Christians who overtly identified with Christianity, but who also acknowledged their African traditions. Participants thus shared a rootedness in both the African and Christian worldviews and related conceptions of God, which will be described. 
TABLE 1

Super ordinate themes identified in the qualitative data

\begin{tabular}{ll}
\hline No.* & Super ordinate themes identified in the qualitative data \\
\hline 12 & Spiritual upbringing; different roles of fathers, mothers, grandparents and church \\
12 & Integration of African and Christian belief systems \\
12 & Changed self-definitions \\
12 & Personal significance \\
12 & Sense of purpose \\
12 & Gratitude \\
12 & God-concept: God is creator of everything \\
12 & God-image: God is a caring parent \\
12 & Prayer an important daily spiritual practice and ritual \\
12 & Apartheid - a sin committed by sinners \\
9 & Traditions are validated in the Bible \\
4 & Fear witchcraft but God is more powerful \\
4 & Acknowledge witchcraft but distances self from it, chooses God \\
2 & Ancestors are guides and are in the service of God \\
2 & Respect traditions but does not share beliefs only believe in God \\
\hline${ }^{*}$ partcipants.
\end{tabular}

\section{RESEARCH FINDINGS AND DISCUSSION}

The main themes (patterns) identified during data analysis are summarised in the following rubric and the number of participants whose views are represented in a particular theme is indicated.

Participants remembered vividly their first uncertain, and frequently confused, steps on their spiritual journey towards the destination of meaning. All participants were committed Christians, but their spiritual upbringing also included African traditional religion, bearing witness to the powerful influence of socialisation on religious awakening (Argyle 2000; Batson, Schoenrade \& Ventis 1993). Traditional religious practices were the domain of the fathers (however, half of the participants' fathers were not involved in their lives), while mothers and grandparents taught Christian religious practices. Despite the fact that no, or very little, verbal teaching and explanation played any role in the early home environment of participants, there were certain rituals such as prayer before meals and at bedtime, as well as forced church attendance coupled with traditional rituals during transition periods, that entrenched beliefs and fostered a powerful awareness of the spiritual realm through emotional, rather than intellectual, pathways (Exline \& Rose 2005). Home-based religious teaching was focused on behavioural and emotional modelling (e.g. rituals and singing) rather than instruction of cognitive knowledge, which was the domain of the church. Bible stories facilitated a cognitive grasp of God and inspired participants from a very early age. Thus, the map for each participant's spiritual journey was designed through a process of socialisation, in which a comfortable syncretism of African and Christian beliefs was transmitted in a process of envelopment (Wilber 2007), where different systems of beliefs were integrated without one necessarily replacing the other. As the magical (African) and mythical (Christian) worldviews share the same fundamental level, the incorporation seemingly presented no problems to the participants. African cosmological assumptions were evident, but were altered, to some degree, by a Christian cosmology. People's cosmology is the space within which they understand events and create meaning.

\section{Four themes regarding the integration of these two belief systems emerged}

Subscription to traditional belief: Most participants still subscribed to the traditional belief in the existence and power of witchcraft, which they associated with evil forces beyond human control, but which could be kept at bay by benevolent spirits (Kasambala 2005). Their awareness of the potential threat of evil was still a source of fear and anxiety and demanded cognitive attention. Participants' fears and anxiety were managed by seeking shelter with, and protection from, God, who is omnipotent.

'There are witchdoctors and God is for good things and witchdoctors are pursuing the devil's business. So the two are still there, even today, I still believe that there are bad spirits out there that people could use to make difficulties for people, although I believe my Christianity is over those beliefs'.

(Andile)

Personal empowerment by belief: A second theme involving the stories of a smaller group of participants is personal empowerment by belief. This group of participants cautiously extracted themselves from the position of subjection to spiritual forces by claiming more personal power through belief. This strategy was very demanding, requiring courage to constantly hold a conscious and vigilant belief; not yet trustingly abdicating to God, but bravely confronting internal and external opposition to change (Peterson \& Park 2004). The consensus was that if one believed in witchcraft, one may be affected, but if one believed in God, then one is protected. By implication, it is not the almighty God but your belief that is the deciding factor.

'You can believe that they are there but you must believe that they won't affect me, because I've got to believe they won't affect me. Sometimes it's ... in your head if you don't believe in them, it won't happen! But, if you say yes, they are there but not towards me then they retreat, they go past'.

(Abel)

Positive role of ancestors: The third group of participants accentuated the positive role of their ancestors but did not externalise evil as the previous groups did. Their focus was on the guidance of their ancestors (whose function in their understanding is similar to the Western idea of 'guardian angels') in daily choices as well as in personal and spiritual growth (Kasambala 2005; Mbiti 1991). They believed and actively experienced their ancestors as involved, wise counsellors, who have their well-being at heart.

'It is advisable to go and get help from a healer and get yourself read, and find out if your ancestors are happy or not, do the rituals you need to do so that you can also be okay. Because I believe it is better to better yourself and to get better understanding of your ancestors than hurt others because that means you are being judgmental and you're being evil .... Because evil is not just Satan. It is your thoughts; it's you wanting bad for another person. And that can end up as translating into action in another person's life'.

Respect and distance: The fourth theme was that participants knew and respected traditional beliefs, but distanced themselves from them. Interestingly, the two participants who were adamant that there was no need for communication with, and veneration of ancestors, and that there was no threat from witchdoctors, were both older than 60 years. Both had a long history of choosing Christian beliefs at important crossroads, probably permanently altering their spiritual paths.

'I respect the things of the African culture because we were growing up with those things but really, we were not yet saved. But, Christians who are saved will tell you, the only truth and the path is God, is Jesus Christ'.

Traditional beliefs and customs were validated when biblical (especially Old Testament) practices and rituals were interpreted as being similar to African traditional ones. So, for instance, as Nehemiah (Neh 2:5) was called to attend to the affairs of his forefathers, Africans are called to attend to their ancestors. Traditional belief in the mediatory role of ancestors is echoed in the function of Jesus and of Mary (among Catholics). Our impression is that the absolute authority that participants attribute to scripture provides an external (external to the African culture) reason to value their African heritage and to claim respect from others. This is significant in the light of a long history of western and Christian imperialism, where everything 
African was shunned. A sense of pride in the collective African heritage is evident.

'Whatever you [Africans] do relates to something in the scripture, in other words when we started learning about the scripture already Africans had beliefs and those beliefs were like, they almost go hand in hand with what we read in the scripture'.

From our Western perspective, the shift from what can be described as a deistic to a theistic God-concept was notable. The transfer to theism brings two main additions to the participants' religious understanding and experience: God as a personal, involved God, and Christ as mediator, either replacing ancestors as mediators, or as the most powerful mediator. Participants accepted that they worshipped the same Supreme Being as is worshiped in the African religion, though in a different way. This understanding eliminates the possibility that anxiety may occur when changes in religious understanding occur. The traditional teachings were viewed as less sophisticated than those of Christianity. The shift from ancestors to Christ as intermediary was easy and beneficial, as no costly rituals were needed; belief in Christ was sufficient. Through Christ (the most powerful ancestor) the way to God was smoothed and made more personal.

'Then I began to understand that our traditions and our beliefs they were that natural attempt to be in contact with God. Though it was limited somehow. But now through my exposure through the Bible I found that the knowledge that I got compliment and even surpasses the knowledge that I had before about God because now it is more closer and more personal. And more direct'.

(Petrus)

A changed self-definition amongst the participants was even more pronounced than the affirmation of African culture. The biblical teaching that humans are created in the image of God was a critical issue regarding positive self-perception.

'From our culture we don't believe that men are created in the image of God. Because nobody knows how God look like. But the Bible tells us that man is created in the image of God. Now it is more closer to God. We are not the creators, but we are something relating to God'.

(Petrus)

Christian religion facilitates a sense of personal, individual (in addition to collective) significance. Participants experienced themselves as being special and equal to every other human being, which links with the belief of being called to make a unique contribution to the lives of fellow 'travellers'. The significance of group solidarity, as expressed by the ubuntu metaphor (Botha 2007) was a cherished African value that provided a sense of significance. The very personal integration of the notion of being God's child and being loved unconditionally, provided another strong bridge to meaning, confirming the principle that participants' perceptions of God were integrally connected with their self-perceptions, their value as human beings and their valuing of others (Tisdale, Doehring \& Lorraine-Poirier 2003).

'Okay I do stuff, there's nothing wrong with me and I know because He lets me know in His own way ... it's a feeling that I have that He accepts me just as I am. He has created me as an individual, as unique'.

(Victoria)

Self-confidence and a new sense of purpose emerge when people identify with the notion of being created in the image of God. Participants viewed themselves as never alone and always protected, freeing mental energy to focus on real obstacles, in addition to providing courage to make decisions at intersections based on faith. Faith frees them from fear of death, living (Bateson et al. 1993), and the fear of unpredictable spiritual forces. Participants were filled with gratitude for their being, life and circumstances irrespective of hardships. Thus, none of the participants saw themselves as victims. They were empowered to make a difference, to affect change, even if only through prayer.

'So, I experienced a lot from my childhood, but God was always with me ... I went through a lot but through the lot I am still surviving.
He protected me ... Before I had my first child, I separated with my husband. He liked to womanise ... I always prayed ... I always said, 'Please God if you want this marriage to work out you are the one who will make it work out.' I used to asked God to change my husband to change his ways, everything that he did. And you know what, slowly, slowly, slowly, slowly, slowly, he was changing, he was changing, until he was fully changed'.

(Kate)

Salient characteristics of participants' God-concept were that God is the creator, the origin of all things. Linked to this God-concept was the image of God being like a parent. Frequently, the Godimage was anthropomorphised, in a sense concretised into a caring, providing powerful human father who is approachable and involved in every intimate detail of daily life resonating with the psychoanalytic view of God as idealised parental figure (Wulff 1997; Rizzuto 1979). He could be trusted to provide, but in return expects, to be pleased and obeyed, like a father in a patriarchal system that provides, but demands, respect, veneration and undivided loyalty. This image puts the onus on the believer, dictating that believers should petition God to get access to the available abundance. God may or may not grant requests. Whether or not such a request is granted, religious attributions are still made (Ozorak 2005). Experiences were perceived as evidence of God's involvement. Gratitude follows when petitions are granted and if not, acceptance that what was not granted would ultimately not have been beneficial, or that the time was not right for God to provide. Any cognitive dissonance was overcome by investing in a superordinate concept (Burris et al. 1997). Like a good parent, he knows best and will act in the best interest of his child.

'He says, I have time for everybody but not at the same time, not at the time of the need, I will come to you when it's your time. Yes, it's all about believing! If I have enough belief in Him, if I trust in Him, at the end of the day I will get what I need. Yes, He takes time to do things because it is not only me, He is not only my father He is fathering everybody. He is a parent to everybody; He needs to go around helping everybody'.

(Thumi)

God is the giver of everything and the almighty protector, but he needs to be reminded to perform these functions and very importantly, one needs to believe - implying that, if you do not believe, you are on your own. Though participants agreed that God punishes those who transgress, none of them interpreted their misfortunes and suffering as punishment. At the junction where choices are made regarding the meaning of events optimistic, growth engendering cognitions prevail. The God-image is a dominant beacon which guides the creation of meaning. If God is good and caring and I believe in Him, everything can be understood and explained. No event or experience seemed to shatter this image of God.

'I used to pray for my kids before they go to school, that God protect them to and back from school. But one morning I never said bye to my children, I even forget to pray. You know what happened that day? One of my daughters was raped. And I could not handle it that the child was raped. I was so bitter, I was angry, you know I said, 'O God how can you do this to me?' But as times goes on it gets better. I saw that God wanted to show me something, because my child was from school and she was grabbed by this guy, he put her in this car. There were three guys but only one guy raped her. So you can imagine how God protected her. Because ... they cannot grab you, three of them and only one do it ... She had to go for HIV tests, at the age of fourteen and she was still protected. Sometimes I think God wanted to show me how big He is. It happened, they never killed her, they took her back to the place that they grabbed her'.

(Kate)

This God-image makes attributions of concern and protection very easy. In retrospect, participants had no difficulty enumerating the obvious evidence of God's love, care and protection, for example having survived in atrocious conditions, not having been attacked in a heated political situation and so on. These 
experiences were interpreted as a clear indication of God's hand in their lives. Difficulties and suffering faded in a process of selective remembering. Even when disaster prevailed and God's expected deliverance was not forthcoming, the God-image was not questioned; rather, the self was doubted:

'My father got ill, had to be operated, he had heart problems, seriously ill. I prayed ... nothing but praying in my heart. I could see that the life of my father was deteriorating drastically. I wanted to know whether really that God is God near me, could hear me. I questioned the presence of God ... my father recover and (did) not die. As of now I am unemployed, I still believe that one day I will get employment but ... sometimes [I think] it's about time [timing] or I don't know whether I am tested, so I think that it is taking too long that I really get what I'm looking for, does God look at me and see maybe how do I suffer. So, truly speaking, I normally doubt myself, I normally doubt when I am in very serious difficulties, because I need help urgently'.

(Andile)

The consensus amongst participants was that God helps those who help themselves. Fortunately, God helps believers to help themselves. By changing his children from within, God gives them courage to proceed.

'What I believe is God only helps those who help themselves. If you sit back and relax and not doing anything, He won't do anything for you. He only helps those who really need His help, who are doing something about it, then He helps you, He comes to your aid but not at the time you that want'.

(Thumi)

God works in and through people, therefore they must do what they can to help themselves and others. He alters the way people interact with others in an internal process in which the conscience plays an important chastising role, motivating a correction of behaviour. Key routes to transformation are prayer and church attendance. Prayer is crucial to all participants. Each participant was formally taught how to pray according to the Lord's Prayer and used the elements of this prayer in his or her own private prayers. It is striking how these aspects shape and strengthen the participants' God-and self-images. Notable is the daily, ritualistic reinforcement of the notion of God as a personal, loving Father involved in the everyday life of his children. The special position of each believer as loved child is affirmed by the invitation by Christ to pray in such an intimate manner. Apart from being a reminder of who God is and what prayer is, prayer also provides an opportunity to the participants for selfreflection. When participants prayed the Lord's Prayer to ask for forgiveness, metacognitive self-assessment and self-regulation was initiated, inviting behavioural change.

'As you know, I am a teacher and I teach 36 kids and at times, you tend to get very harsh on those kids. After that, I say, 'O God I am sorry.' You know I do not like to hurt people; I don't like to make things that I know I should not make'.

Through prayer believers learn and develop new perspectives. While talking to a loving Father who teaches endurance and humility, a person can transform a victim mentality by developing a new perspective on life and by positive reframing (Exline \& Rose 2005; Pargament \& Mahoney 2002).

I got to the point where it is okay for me to go through hardship because at first I did not understand it, I felt like a victim. I felt like, why me, why do I have to suffer so much and in His own way He explained to me that this is the way for you to learn'.

(Victoria)

Participants accentuated the importance of praying mindfully and in belief. If you prayed without believing then your prayer would not be heard. In this sense, the onus was on the one who prayed; the strength of your belief was the deciding factor and not the love or power of the giver.

'If today I question the way, I prayed then I pray tomorrow, the time the answers come, I won't say which one has been heard, but I am happy about the results, the response from God'.

(Andile)
Praying was not just a cognitive activity, but provided emotional release. Communal prayer, singing and other religious rituals were emotionally rewarding and important triggers for religious experiences (Argyle, 2000). Private prayer also provided a frequent opportunity for emotional catharsis.

'Our Father who art in heaven, nothing is greater than that kind of praying. You can go further, you know when you start saying 'Our Father, who art in heaven', then it comes, there comes those words as to how can you really pray, you now pray and pray and pray and pray until you find yourself crying and when things cool down, you go back to that prayer again. To pray ... is something that comes, it comes, it comes, whether you like it or not, it comes as long as you have invited Jesus to be with you when you are praying, really, because now you are giving your whole heart to this kind of thing and then it becomes something that takes you up, the Holy Spirit'.

(Joseph)

Religion changes people's attitude to life (Argyle 2000). Cognitions, emotions and behaviours are fundamentally altered, generally to the benefit of the believer and society. Love, as the ultimate spiritual-religious beacon, is taught, experienced and lived. How then does the believer translate religious-spiritual attitudes into day-to-day living? A decisive test of the depth and staying-power of new attitudes might be the believer's reactions to injustice and suffering, of which the epitome, in the case of the participants, may possibly have been the Apartheid system. It was a system that was ostensibly grounded on solid biblical principles, but which devalued many humans, a system where certain racial groups were treated atrociously. Mostly white people, whom the system benefitted, were audacious enough to preach the Gospel based on their interpretation to the disenfranchised (mostly Black and Coloured people). The participants took a spiritual perspective on their Apartheid experiences: God is good, humans are good, but they do sin, Apartheid was a sinful aberration and not the will of God. Woven into this view was a humility that arose from an acknowledgement and repentance of one's limitations and sins. This was a platform that set the participants free from any harmful internalisations of being inferior human beings, which was the subtext of Apartheid. The most travelled roads to the destination of meaning of Apartheid were biblical teachings, personal experience, forgiveness and prayer, all of which paved the way to a better state of well-being.

'I had this vision of Apartheid but I never put God anywhere in there. For the first time I wanted to put God in it, I wanted to understand, where was God in this whole thing. God created the world and everything and He put man there. In Genesis, He says I put you to take charge and control of everything. But then, like other people are in authority and sometimes they put their interest before God's interest. Other people do that and other people may suffer, but it's not how God wants it. I spent a lot of my life with my grandparents because my father was not caring, so it's not because we wanted it to be like that, it's because of the selfishness of my father that he wanted to do whatever he wanted to do, forgetting about ugly children, but it's not how God wanted it. So if it's like that, then God will find another way of helping those who are trapped in a situation, but He is not the one who put it there'.

(Peter)

After 1994, South Africans began to take note of their fellow travellers. Mandela's wisdom, forgiveness and quest for reconciliation served as an authoritative example. The more open echelons of society altered stereotypes of wealthy, unburdened white folk as being God's chosen. Now all people were considered equal in the eyes of God: subjected to the same laws, personally responsible for their choices and the consequences thereof.

'When I was at high school I was very bitter. I always taught God is white. Why are only whites rich, why are we suffering, why are our parents living like this? ... As we grow up we read ...That time we used to like memorise the Bible ... [Now you] read the Bible and you sit down and try to analyse and understand. The year after 
1994, after those changes I learned so much. It is not bad, we are all the same. God is doing the same to others. It is only how you live your life, how you control your life that makes you what you are. It is not about God and the colour'.

The obstacle of injustice was bridged in the space of unconditional love, where the children (the participants) communicated with their Father who they regarded as being ultimately in control.

'Such things [Apartheid] bring confusion into my life, a huge confusion and I would try to understand that He created each and every one of us... He has created those things that were happening and I always question Him, not questioning His abilities, I question Him like asking questions. You created us in this way and yet such things happened in your presence, were you trying to bring life to us through those experiences so that we could become the strong people that we are? ... But ... He shows me that no, these things happened ... not because you deserve to be in pain, but you go through everything that happens as a lesson. You always understand Him in order to identify Him in this whole thing, because lately we went through such dangers in our life and it was very difficult and we would think where was He? But He was there waiting for us to learn'.

(Victoria)

\section{CONCLUSION}

In this article, the unique role of religion in providing meaning in the life of participants and contributing to their well-being was described. All participants were brought up in extended families that transmitted both African and Christian religions and had powerful attachment-figures, arguably providing the foundation for the creation of a benevolent God-image of an exalted parental figure (Rizzuto 1979), making available a psychologically safe room for growth and development. In a movement, away from passive subjugation to unpredictable forces to submission to a loving omnipotent parental figure, horizons of new spiritual heights were expanded from where new life possibilities of freedom and personal responsibility were reached.

However, the safety was not uncontaminated by fear, which was only managed, but not overcome as both African and Christian religions are fear-based (Wilber 2007). It is striking that a true sense of security eluded all (but one) of the participants. Their personal understanding of both the African and Christian religious principles did not facilitate a sense of absolute security and trust in the goodness of God as an independent given, unrelated to the strength of their belief or quality of their service. Total freedom arguably is the result of total surrender to God, which seems to indicate a different spiritual truth - freedom in surrender. This appears paradoxical, because true surrender goes against the very human need to have freedom of choice, be self-reliant and in control and this remains an ongoing struggle in theistic religions (Exline \& Rose 2005). The metanarrative of total surrender to God, however, is freedom.

Although all participants had experiences that could have triggered feelings of anger towards God (only two acknowledged to ever having had such feelings), their positive, theistic Godimage probably absorbed and blotted out the anger and disappointment, consequently restoring the feeling of closeness and connectedness to God.

Participants, who can all be described as intrinsically religious, created meaning in the light of the tenets of African and Christian religion they accepted and individually forged into an integrated worldview or system of meaning. The power of this system to frame understanding and make sense of experiences was explicated, highlighting the crucial role of feeling individually significant and safe. A theistic concept and image of God as a sovereign and benevolent parent provided the participants with a sense of purpose, enhanced self-esteem, hope and motivation
(Geyer \& Baumeister 2005; Argyle 2000). Extraordinary suffering and other belief-disconfirming experiences only served to intensify participants' beliefs, through processes of religious attributions and reconciliation of contradicting beliefs and experiences into super-ordinate concepts (Burris et al. 1997), providing the participants with strength to pursue their life goals and to live according to their values of love and service. Through their God-belief, participants attained a sense of self-efficacy, as they obtained some control over their lives, banishing feelings of being at the mercy of unpredictable forces and gaining interpretive control, because they were able to create understanding with respect to the reason for life's occurrences (Baumgardner \& Crothers 2009). The repetitive exercise of benefit-finding and benefit-reminding through prayer, church attendance and sharing amongst one another enhanced their human strength, optimism and hope, contributing to their wellbeing (Tennen \& Affleck 2002)

Religious assurances of each individual's uniqueness and importance bolstered their self-worth and their belief that humans are co-creators and helpers of God enhanced their sense of self-efficacy in the assurance that with God's help humans can overcome all obstacles. In accepting life as a journey with God, participants met challenges with confidence and responsibility. Their focus was on building and contributing to society, as opposed to angry entitlement. The God-belief of participants contributed to them expressing the key dimensions of psychological well-being, notably the following:

- virtues of humanity expressed in love and social intelligence

- temperance expressed in forgiveness and mercy, and

- transcendence expressed in their gratitude, the meaning they create through their religiousness and spirituality (Van Eeden et al. 2008).

Even though religious devotion brings freedom at the cost of bondage to the belief system itself (Batson et al. 1993), the participants did not experience this 'limited' freedom as a burden. They coped with adversity in the light of their orienting system to forge a valuable meaningful life. Finally, the insights gained in this study about the role that religion plays in the creation of meaning and the contribution of religion to the psychological well-being of Christians from an African context could be translated into psychological practice. The practice fields of pastoral counselling and trauma counselling can base therapeutic interventions and/or guidance on the fact that religious beliefs and practices can provide a basis for a transcendent sense of personal growth, efficacy, mastery and purpose in life. Experiences of adversity can be worked through by means of religious coping methods and the optimism and hope that religious affiliation seems to instil in people's views. The findings of this study suggest that religious beliefs and experiences may provide an important source of personal strength that promotes psycho-social well-being, mental and physical health and positive emotions such as joy, gratitude, forgiveness, hope and optimism - all building blocks of psychological well-being. Religion offers a unique and special source of meaning concerning human existence and purpose that may be a powerful enabling strength when confronting life-threatening experiences or illness (Baumgardner \& Crothers 2009).

\section{REFERENCES}

Alvesson, M., 2002, Postmodernism and social research, Buckingham, Open University Press.

Argyle, M., 2000, Psychology and religion: An introduction, Routledge, London.

Babbie, E. \& Mouton, J., 2001, The practice of social research, Oxford University Press, Oxford.

Babbie, E., 2007, The practice of social research, 11th edn. Thomsom-Wadworth, Belmont, CA.

Batson, D.C, Schoenrade, P \& Ventis, W.L., 1993, Religion and the individual: A social-psychological perspective, Oxford Press, New York. 
Baumeister, R.F., 1991, Meanings of life, Guilford Press, New York. Baumeister, R.F. \& Vohs, K.D., 2002, 'The pursuit of meaningfulness in life', in C.R. Snyder \& S.H. Lopez (eds.), Handbook of positive psychology, pp. 608-618, Oxford University Press, Oxford.

Baumgardner, S.R. \& Crothers, M.K., 2009, Positive psychology, Prentice Hall, Upper Saddle River.

Botha, J.E., 2007, 'Exploring issues around Biblical, Western and African social Values', HTS Teologiese Studies/Theological Studies 63(1), 147-169.

Burrell, G. \& Morgan, G., 1979, Social paradigms and organisational analysis, Heinemann, London.

Burris, C.T., Hammond-Jones, E. \& Trapley, W.R., 1997, ' "By faith alone" Religious agitation and cognitive dissonance', Basic and Applied Social Psychology 19(1), 17-31.

Compton, W.C., 2005, An introduction to positive psychology, Thompson-Wadsworth, Belmont, CA.

Craffert, P.F., 2008, The life of a Galilean shaman, Jesus of Nazareth in anthropological-historical perspective, Cascade Books, Oregon.

Creswell, J.W., 1994, Research design, qualitative $\mathcal{E}$ quantitative approaches, Sage Publications, Thousand Oaks.

Dennett, D.C., 2006, Breaking the spell, Religion as a natural phenomenon, Allen Lane, London.

Diener, E., Suh, E.M., Lucas, R.E. \& Smith, H.L., 1999, 'Subjective well-being: Three decades of progress', Psychological Bulletin $125,274-302$.

Dreyer, Y., 2003, 'Beyond psychology: Spirituality in Henri Nouwen's pastoral care', HTS Teologiese/Theological Studies 59(3), 715-733.

Emmons, R.A., 2006, 'Spirituality: Recent progress', in M. Csikszentmihalyi \& S.I. Csikszentmihalyi (eds.), A life worth living: Contributions to positive psychology, pp. 62-84, Oxford University Press, New York.

Exline, J.E. \& Rose, E., 2005, 'Religious and spiritual struggles', in R.F. Paloutzian \& C.L. Park (eds.), Handbook of the psychology of religion and spirituality, pp. 315-330, The Guilford Press, New York.

Frankl, V.E., 1978, Waarom lewe ek [Man's search for meaning], HAUM, Cape Town.

Festinger, L., 1957, A theory of cognitive dissonance, Stanford University Press, Stanford.

Gadamer, H.G., 1982, Lectures on philosophical hermeneutics, Van Schaik, Hatfield.

Geyer, A.L. \& Baumeister, R.F., 2005, 'Religion, morality and self-control: Values, virtues and vices', in R.F. Paloutzian \& C.L Park (eds.), Handbook of the Psychology of religion and spirituality, pp. 216-234, The Guilford Press, New York.

Goodwin, A., 1998, 'Freud and Erikson: Their contribution to the psychology of God Image formation', Pastoral Psychology 47(2), 97-117.

Gorsuch, R.L. \& Smith, L.S., 1983, 'Attributions of responsibility to God: An interaction of religious beliefs and outcomes', Journal for the Scientific Study of Religion 22(4), 340-352.

Grbich, C., 2007, Qualitative data analysis: An introduction, Sage Publications, London.

Guba, E.G. \& Lincoln, Y.S., 1994, 'Competing paradigms in qualitative research', in H.K. Denzin \& Y.S. Lincoln (eds.), Handbook of qualitative research, pp. 105-117, Sage Publications, Thousand Oaks.

Guthrie, S.E., 1993, Faces in the clouds. A new theory of religion, Oxford University Press, New York.

Hammond-Tooke, D., 1998, 'Establishing dialogue: Thoughts on "cosmology", "religion" and "science"' in C.W. Du Toit (ed.), Faith, science and African culture: African cosmology and Africa's contribution to the future of science, pp. 1-9, Unisa, Pretoria.

Hertog, K. \& Gow, K.M., 2005, 'Religious attributions pertaining to the causes and cures of mental illness', Mental Health, Religion \& Culture 8(4), 263-276.

Jones, K., 2004, 'Mission drift in qualitative research, or moving toward systematic review of qualitative studies, moving back to more systematic narrative review', The Qualitative Report 9(1), 95-112.
Kalilombe, P.A., 1994, 'Spirituality in African perspective', in R. Gibellini (ed.), Paths of African theology, pp. 115-135, Orbis Books, New York.

Kalilombe, P.A., 1999, Doing theology at the grassroots: Theological essays from Malawi, Mambo Press, Zomba.

Kasambala, A.E., 2005, 'The impact of an African spirituality and cosmology on God-images in Africa: A challenge to practical theology and pastoral ministry', International Journal of Practical Theology 9(2), 300-323.

Kelly, K., 2007a, 'From encounter to text: Collecting data in qualitative research', in M. Terre Blanche, K. Durrheim \& D. Painter (eds.), Research in practice, Applied methods for the social sciences, pp. 285-319, University of Cape Town Press, Cape Town.

Kelly, K., 2007b, 'Lived experience and interpretation: The balancing act in qualitative analysis', in M. Terre Blanche, K. Durrheim \& D. Painter (eds.), Research in practice: Applied methods for the social sciences, pp. 345-369, University of Cape Town Press, Cape Town.

Kelly, K., 2007c, 'Calling it a day: Reaching conclusions in qualitative research', in M. Terre Blanche, K. Durrheim \& D. Painter (eds.), Research in practice: Applied methods for the social sciences, pp. 370-380, University of Cape Town Press, Cape Town.

Koltko-Rivera, M.E., 2004, 'The psychology of worldviews', Review of General Psychology 8(1), 3-58.

Lawrence, R.T., 1997, 'Measuring the image of God: The God image inventory and the God image scale', Journal of Psychology and Theology 25(2), 214-226.

Leontiev, D., 2006, 'Meaningful living and the worlds of art', in A. Della Fave (ed.), Dimensions of well-being, pp. 529-537. FrancoAngel, Milano.

Maree, K. \& Pietersen, J., 2007, 'Sampling', in K. Maree (ed.), First steps in research, pp. 169-181, Van Schaik, Pretoria.

Mbiti, J.S., 1991, Introduction to African religion, 2nd edn., Heinemann, Blantyre.

Meier, A. \& Meier, M., 2004, 'Formation of adolescents' image of God: Predictors and Age and gender differences', American Journal of Pastoral Counseling 7(2), 91-111.

Montell, C., 2001, 'Speculations on a privileged state of cognitive dissonance', Journal for the Theory of Social Behaviour 31(2), 119-137.

Nieuwenhuis, J., 2007a, Introducing qualitative research, in K. Maree (ed.), First steps in research, pp. 47-68, Van Schaik, Pretoria.

Nieuwenhuis, J., 2007b, 'Qualitative research design and data gathering techniques', in K. Maree (ed.), First steps in research, pp. 70-97, Van Schaik, Pretoria.

Nieuwenhuis, J., 2007c, 'Analysing qualitative data', in K. Maree (ed.), First steps in research, pp. 99-123, Van Schaik, Pretoria.

Nürnberger, K., 2007, The living dead and the living God: Christ and the ancestors in a changing Africa, Cluster Publications, Pietermaritzburg.

Ozorak, E.W., 2005, 'Cognitive approaches to religion', in R.F Paloutzian \& C.L. Park (eds.), Handbook of the psychology of religion and spirituality, pp. 216-234, The Guilford Press, New York.

Pargament, K.I., 1997, The psychology of religion and coping: Theory, research, practice, The Guilford Press, New York.

Pargament, K.I. \& Hahn, J., 1986, 'God and the just world. Causal attributions and coping attributions to God in health situations', Journal for the Scientific Study of Religion 25(2), 193-207.

Pargament, K.I \& Mahoney, A., 2002, 'Spirituality, Discovering and Conserving the Sacred', in C.R Snyder \& J.L. Shane (eds.), Handbook of positive psychology, pp. 646-659, Oxford University Press, Oxford.

Park, C.L., 2005, 'Religion and meaning', in R.F Paloutzian \& C.L. Park (eds.), Handbook of the psychology of religion and spirituality, pp. 295-330, The Guilford Press, New York.

Peterson, C. \& Park, N., 2004, 'Classification and measurment of character strengths: Implications for practice', in P.A. Linley \& S. Joseph (eds.), Positive psychology in practice, pp. 433-446, John Wiley \& Sons, Hoboken, NY. 
Peterson, C. \& Seligman, M.E.P., 2004, Character strengths and virtues: A handbook and classification, Oxford University Press, (DC).

Post, S.G., 1996, 'Ethics, religion, and mental health', in H.G. Koenig (ed.), Handbook of religion and mental health, pp. 21108, Academic Publishers, San Diego.

Pyysiäinen, I., 2003, 'True fiction: Philosophy and psychology of religious belief', Philosophical Psychology 16(1), 109-125.

Rassool, G.H., 2000, 'The crescent and Islam: Healing, nursing and the spiritual mdimension.m Some considerations towards an understanding of the Islamic perspectives on caring', Journal of Advanced Nursing 32(6), 1476-1484.

Rizzuto, A.M., 1979, The birth of the living God. A psychoanalytic study, Chicago University Press, Chicago.

Ryff, C.D. \& Singer, B., 1996 'Psychological well-being: Meaning, measurement and implication for psychotherapy research' Psychotherapy and Psychosomatics 65(1), 14-23.

Schwandt, T.A., 1994, 'Constructivist, interpretivist approaches to human inquiry', in H.K. Denzin \& Y.S. Lincoln (eds.), Handbook of qualitative research, pp. 118-137, Sage Publications, Thousand Oaks.

Seligman, M.E.P., 2002, Authentic happiness: Using the new positive psychology to realize your potential for lasting fulfilment, Free Press, New York.

Sossis, R., 2006, 'Religious behaviors, badges, and bans: Signaling theory and the evolution of religion', in P. McNamara (ed.), Where God and sciences meet: How brain and evolutionary studies our understanding of religion, pp. 61-86, Praeger Publishers, Westport, CT.

Spong, J.S., 1999, Why Christianity must change or die: A bishop speaks to believers in exile, Harper, San Francisco.

Spong, J.S., 2001, A new Christianity for a new world: Why traditional faith is dying and how a new faith is being born Harper, San Francisco.
Taylor, S.J \& Bogdan, R., 1998, Introduction to qualitative research methods: A guidebook and resource, 3rd edn., John Wiley and Sons, New York.

Tennen, H. \& Affleck, G., 2002, 'Benefit-finding and benefitreminding', in C.R. Snyder \& J.L. Shane (eds.), Handbook of positive psychology, pp. 584-597, Oxford University Press, Oxford.

Terre Blanche, M., Durrheim, K. \& Kelly, K., 2007, 'First steps in qualitative data analysis', in M. Terre Blanche, K. Durrheim \& D. Painter (eds.), Research in practice: Applied methods for the social science, pp. 320-344, University of Cape Town Press, Cape Town.

Tisdal, T.S., Doehring, C.E. \& Lorraine-Poirier, V., 2003, ‘Three voices, one song: A psychologist, spiritual director, and pastoral counsellor share perspectives on providing care', Journal of Psychology and Religion 31(1), 52-68.

Van Eeden, C., Wissing, M.P., Dreyer, J., Park, N. \& Paterson, C., 2008, 'Validation of the Values in Action Inventory of Strengths for Youth (VIA-Youth) among South African learners', Journal of Psychology in Africa 18(1), 134-143.

Viljoen, H., 2003, 'African perspectives', in W. Meyer, C. Moore \& H. Viljoen (eds.), Personology. From individual to ecosystem, 3rd edn., pp. 528-549, Heinemann, Sandown.

Western, D., 1999, Psychology: Mind, brain \& culture, 2nd edn., John Wiley and Sons, New York.

Wilber, K., 2007, The integral vision, Shambhala, Boston.

Wissing, M.P. \& Temane, Q.M., 2008, 'The structure of psychological well-being in cultural context: Towards a hierarchical model of psychological health', Journal of Psychology in Africa 18(1), 45-56.

Wulff, D.M.,1997, Psychology of religion: Classic and contemporary, John Wiley and Sons, New York.

Zahan, D., 2000, 'Some reflections on African spirituality' in J.K Olupona (ed.), African Spirituality: Forms, meanings and expressions, pp. 3-25, Herder and Herder, New York. 